\title{
Direct Aerobic Generation of a Ferric Hydroperoxo Intermediate Via a Preorganized Secondary Coordination Sphere
}

\author{
Kate A. Jesse, Sophie W. Anferov, Kelsey A. Collins, Juan A. Valdez-Moreira, Maia E. Czaikowski, \\ Alexander S. Filatov, and John S. Anderson*
}

Cite This: J. Am. Chem. Soc. 2021, 143, 18121-18130

Read Online

ABSTRACT: Enzymes exert control over the reactivity of metal centers with precise tuning of the secondary coordination sphere of active sites. One particularly elegant illustration of this principle is in the controlled delivery of proton and electron equivalents in order to activate abundant but kinetically inert oxidants such as $\mathrm{O}_{2}$ for oxidative chemistry. Chemists have drawn inspiration from biology in designing molecular systems where the secondary coordination sphere can shuttle protons or electrons to substrates. However, a biomimetic activation of $\mathrm{O}_{2}$ requires the transfer of

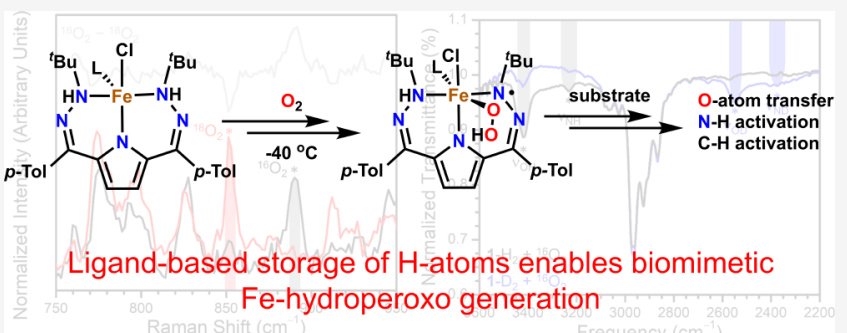
both protons and electrons, and molecular systems where ancillary ligands are designed to provide both of these equivalents are comparatively rare. Here, we report the use of a dihydrazonopyrrole (DHP) ligand complexed to Fe to perform exactly such a biomimetic activation of $\mathrm{O}_{2}$. In the presence of $\mathrm{O}_{2}$, this complex directly generates a high spin $\mathrm{Fe}$ (III)-hydroperoxo intermediate which features a $\mathrm{DHP} \bullet$ ligand radical via ligand-based transfer of an $\mathrm{H}$ atom. This system displays oxidative reactivity and ultimately releases hydrogen peroxide, providing insight on how secondary coordination sphere interactions influence the evolution of oxidizing intermediates in Fe-mediated aerobic oxidations.

\section{INTRODUCTION}

Enzymatic systems and, in particular, metalloenzymes mediate a fascinating array of reactions via a carefully evolved secondary coordination sphere. Enzyme active sites leverage effects such as hydrogen bonding, electron transfer pathways, and electrostatic effects to precisely tune the reactivity of metallocofactors. ${ }^{1,2,11,3-10}$ One example illustrating the importance of the secondary coordination sphere is in oxidase chemistry. For example, the terminal oxidant in cytochrome P450 enzymes, Compound I, consists of an $\mathrm{Fe}(\mathrm{IV})$-oxo which is generated from $\mathrm{O}_{2}$ via the delivery of proton and electron equivalents from cofactors and the protein superstructure. Other enzymes, such as cytochrome $\mathrm{C}$ oxidase, selectively reduce molecular $\mathrm{O}_{2}$ to water with the controlled addition of reducing equivalents mediated by an elaborate secondary coordination sphere. ${ }^{12-16}$ While the reactivity and ultimate products of oxidases are varied, the initial steps in $\mathrm{O}_{2}$ activation can be quite general, proceeding through initial binding of $\mathrm{O}_{2}$ to generate an $\mathrm{Fe}$ superoxide intermediate before further activation to an $\mathrm{Fe}$ (III)-hydroperoxo intermediate by the addition of a formal $\mathrm{H}$ atom from the active site. ${ }^{12-19}$

Molecular chemists have drawn inspiration from these elegant biological examples, and the use of ancillary ligands with designed hydrogen bonding networks, ${ }^{20-23}$ hydrogen shuttling functionalities, ${ }^{24-30}$ or redox reservoirs have emerged as promising strategies in transition metal reactivity and catalysis. $^{31-40}$ While these strategies are effective individually, natural systems are not limited to one interaction type in the secondary coordination sphere but instead leverage all of these effects. For instance, the generation of $\mathrm{Fe}$ (III)-hydroperoxo intermediates in the oxidase chemistry discussed above requires the controlled delivery of both protons and electrons, or equivalently $\mathrm{H}$-atoms, to $\mathrm{O}_{2}$. In contrast, synthetic examples of $\mathrm{Fe}(\mathrm{III})$-hydroperoxo intermediates are almost always generated with exogenous reducing or acid equivalents. ${ }^{41,42,51,52,43-50}$ There are effectively no examples of welldefined $\mathrm{Fe}$ (III)-hydroperoxo intermediates generated via biomimetic $\mathrm{H}$-atom transfer from a designed secondary coordination sphere, with one lone example arising from adventitious activation of a supporting ligand. ${ }^{53}$

Synthetic systems where designed ancillary ligands can donate both protons and electrons have been an area of increasing interest. ${ }^{3,23,62-68,54-61}$ However, leveraging this strategy for the biomimetic activation of $\mathrm{O}_{2}$ has not been explored. We reasoned that the previously reported pyrrolebased ligand scaffold ${ }^{t \mathrm{Bu}, \mathrm{Tol}} \mathrm{DHP}\left({ }^{t \mathrm{Bu}, \mathrm{Tol}} \mathrm{DHP}=2,5\right.$-bis $((2-t$ butylhydrazono)(p-tolyl)methyl)-pyrrole, Scheme 1), which

Received: July 3, 2021

Published: October 26, 2021 
Scheme 1. Metalation of ${ }^{\mathrm{tBu}, \mathrm{Tol}} \mathrm{DHP}-\mathrm{H}_{2} \cdot 2 \mathrm{HCl}$ with $\mathrm{FeCl}_{2}$

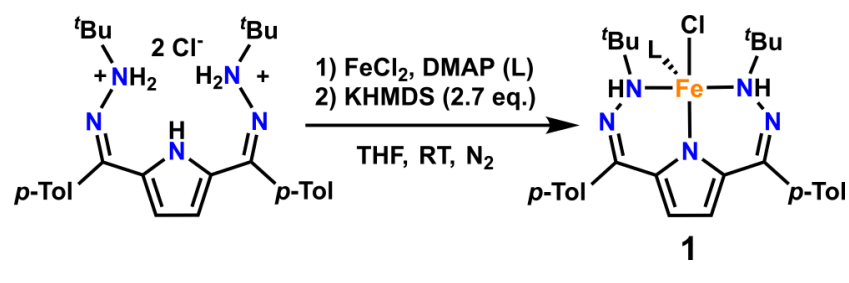

can donate two electrons and two protons to a substrate, would be an ideal scaffold to demonstrate this principle. ${ }^{69}$ Here, we show that the preorganization of protons and electrons on this ligand scaffold allows for the direct formation of an $\mathrm{Fe}$ (III)-hydroperoxo intermediate from $\mathrm{O}_{2}$, mirroring the type of reactivity and preorganization found in the protein superstructure of biological systems. This Fe(III)-hydroperoxo intermediate has been characterized by a variety of spectroscopic techniques in addition to kinetic and computational analysis. Reactivity studies show that this system performs both $\mathrm{O}$-atom transfer and $\mathrm{H}$-atom abstraction. Finally, warming of this system results in the formation of a putative dehydrogenated $\mathrm{Fe}$ complex along with generation of some $\mathrm{H}_{2} \mathrm{O}_{2}$, providing insight on how the secondary coordination sphere can tune the evolution and terminal products in oxidase-like systems. This investigation demonstrates the utility of redox-active ligands that are also proton responsive for facilitating small molecule activation and aerobic oxidative reactivity.

\section{RESULTS AND DISCUSSION}

Synthesis and Characterization of 1. The dihydrazonopyrrole ligand, ${ }^{t \mathrm{Bu}, \mathrm{Tol}} \mathrm{DHP}$ was isolated as a dication as described previously and metalated via addition to a solution of $\mathrm{FeCl}_{2}$ and dimethylaminopyridine (DMAP) in THF, followed by the addition of 2.7 equiv of potassium hexamethyldisilazide (KHMDS). ${ }^{70}$ After workup, an orange powder was isolated in $71 \%$ mass yield. Orange crystals suitable for single crystal X-ray diffraction (SXRD) reveal the structure of this orange product to be $\mathrm{Fe}\left({ }^{t \mathrm{Bu}, \mathrm{Tol}} \mathrm{DHP}-\mathrm{H}_{2}\right)(\mathrm{DMAP}) \mathrm{Cl}(1$, Scheme 1; see Figure S29). The H's on the $\beta$-N of the hydrazone moieties were found in the difference map and further confirmed by stretches at 3182 and $3170 \mathrm{~cm}^{-1}$ via infrared (IR) spectroscopy (see Figure S16). The geometry of $\mathbf{1}$ is best described as pseudosquare pyramidal with a $\tau_{5}$ value of $0.017 .^{71}$ The protonation of the $\beta$-N's results in a twisting of the $t$-butyl groups of the hydrazone arms out of the ligand plane and an overall asymmetric complex in the solid state. This asymmetry in the solid state structure results in one of the $\beta$ - $\mathrm{N} \mathrm{H}$-atoms being positioned close to where a substrate is most likely bind to the Fe-center, thus creating a promising environment for substrate hydrogenation via $\mathrm{H}$-atom abstraction from the ligand.

The $\mathrm{Fe}-\mathrm{N}$ bond lengths were found to be 2.399(2) and 2.362(2) $\AA$ to the hydrazone arms and 2.035(2) $\AA$ to the pyrrole $\mathrm{N}$, consistent with a high spin $\mathrm{Fe}(\mathrm{II})$ center. ${ }^{72,73}$ This spin and oxidation state for the $\mathrm{Fe}$ center was further supported by solution state magnetic measurements, with $\mu_{\text {eff }}$ $=5.0 \mu_{\mathrm{B}}$ by Evans method. ${ }^{74,75}$ Both experiments are consistent with the expected $S=2$ spin for a high spin $\mathrm{Fe}(\mathrm{II})$ complex. EPR spectroscopy in parallel mode on a $15 \mathrm{mM}$ solution in toluene at $15 \mathrm{~K}$ shows a broad feature at $g=8.4$, which is also consistent with an $S=2$ complex. The paramagnetic nature of 1 was further supported via ${ }^{1} \mathrm{H}$ NMR in $\mathrm{C}_{6} \mathrm{D}_{6}$, which features 7 broad features ranging from 29.2 to $3.4 \mathrm{ppm}$. Nine features in the ${ }^{1} \mathrm{H}$ NMR would be expected assuming a symmetric ${ }^{t \mathrm{Bu}, \mathrm{Tol}} \mathrm{DHP}-\mathrm{H}_{2}$ ligand in solution. This suggests that some features, likely those with higher proximity to the high spin $\mathrm{Fe}$ (II) center, have been broadened or shifted to such an extent that they are no longer visible. It further suggests that the hydrazone arms, which are inequivalent in the solid-state, equilibrate in solution at room temperature.

Aerobic Reactivity. The reaction of molecular $\mathrm{O}_{2}$ with 1 in toluene was monitored at low temperature by UV-visible spectroscopy (Figure 1). The spectrum of complex $\mathbf{1}$ is largely featureless at wavelengths longer than $400 \mathrm{~nm}$. Upon addition of excess $\mathrm{O}_{2}$ to a $0.35 \mathrm{mM}$ solution in toluene at $-60{ }^{\circ} \mathrm{C}$, broad features grow in throughout the spectrum assigned as a new intermediate or mixture, 2 (Figure 1A). After $20 \mathrm{~min}$, further evolution to a new species, 3, is observed (Figure 1B). The conversion between $\mathbf{1}$ to $\mathbf{2}$ and eventually $\mathbf{3}$ is convoluted, potentially due to the short lifetime of $\mathbf{2}$ even at temperatures as low as $-80{ }^{\circ} \mathrm{C}$. As such, only the feature at $996 \mathrm{~nm}$ can be concretely assigned to $\mathbf{2}$. Conversely, intermediate $\mathbf{3}$ is stable once formed under these conditions and persists without noticeable decomposition at temperatures up to $-40{ }^{\circ} \mathrm{C}$, with features at 528 and $716 \mathrm{~nm}$. Further evolution of the spectrum is observed above these temperatures to form 4 (Figure 1). The relative stability of 3 led us to investigate its assignment more thoroughly.

Characterization of Intermediate 3. Kinetic studies were conducted to better understand the transformations observed by UV-visible spectroscopy. Kinetic analysis of the transformation from $\mathbf{1}$ to $\mathbf{2}$ was conducted under pseudo firstorder conditions by monitoring the growth and disappearance of the peak in the UV-visible spectrum at $996 \mathrm{~nm}$ to avoid overlap with features from 3 . The transformation from 1 to 2 did not fit standard zero-, first-, or second-order kinetics well. This suggests a complicated pre-equilibrium or that 2 is a mixture of products. Consistent with this hypothesis, Mössbauer spectra of a frozen solution of $\mathbf{2}$ show a complicated mixture of species, likely due to the transient nature of $\mathbf{2}$, its speciation, or other intermediates or byproducts present in the solution (see Figure S26). In contrast, the transformation from the major species in $\mathbf{2}$ to complex $\mathbf{3}$ was found to follow first-order kinetics in $\mathrm{Fe}$ using an exponential fit of the data (see Tables S2-S8). Eyring analysis of the transformation from 2 to 3 gives an $\Delta H^{\ddagger}=7.6(1.0) \mathrm{kcal} / \mathrm{mol}$ and $\Delta S^{\ddagger}=-34(4.9) \mathrm{cal} /(\mathrm{mol} \mathrm{K})^{-1}$. We also monitored the reaction of $\mathrm{O}_{2}$ with $\mathrm{N}-\mathrm{D}$ deuterated complex 1 to examine the KIE for the formation of 3 (see Figure S30, Tables S9-S11). While the error in the rates is sufficiently large to preclude any concrete conclusions, the data does reveal a small KIE of around 1 . This suggests that the rate determining step for the formation of $\mathbf{3}$ does not involve $\mathrm{H}$-atom or proton transfer, as might be expected for a rate determining ligand association or dissociation. The significant and negative entropy of activation for this conversion is also consistent with a rate determining ligand association, but this interpretation is tentative without more detailed kinetic analysis.

The first-order kinetics in the conversion of $\mathbf{2}$ to $\mathbf{3}$ in the UV-visible spectra suggest that the nuclearity of the $\mathrm{Fe}$ complexes is maintained in this transformation. This observation suggests that if $\mathbf{2}$ were mononuclear, bimolecular pathways could be ruled out. To test this hypothesis, reactions at $-40{ }^{\circ} \mathrm{C}$ with 0.5 equiv and 1 equiv of $\mathrm{O}_{2}$ were monitored by 

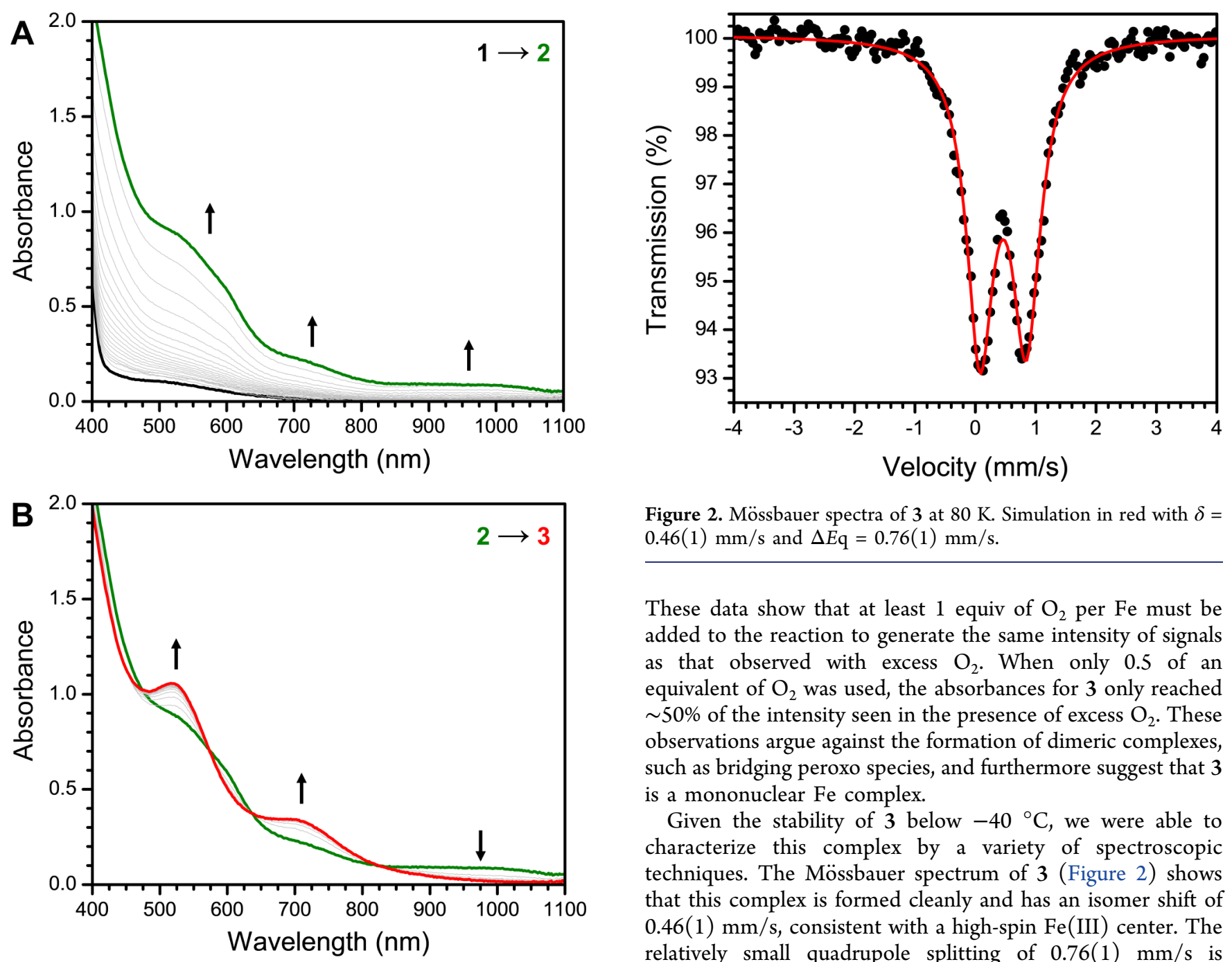

Figure 2. Mössbauer spectra of 3 at $80 \mathrm{~K}$. Simulation in red with $\delta=$ $0.46(1) \mathrm{mm} / \mathrm{s}$ and $\Delta E \mathrm{q}=0.76(1) \mathrm{mm} / \mathrm{s}$.

These data show that at least 1 equiv of $\mathrm{O}_{2}$ per $\mathrm{Fe}$ must be added to the reaction to generate the same intensity of signals as that observed with excess $\mathrm{O}_{2}$. When only 0.5 of an equivalent of $\mathrm{O}_{2}$ was used, the absorbances for 3 only reached $\sim 50 \%$ of the intensity seen in the presence of excess $\mathrm{O}_{2}$. These observations argue against the formation of dimeric complexes, such as bridging peroxo species, and furthermore suggest that 3 is a mononuclear Fe complex.

Given the stability of 3 below $-40{ }^{\circ} \mathrm{C}$, we were able to characterize this complex by a variety of spectroscopic techniques. The Mössbauer spectrum of 3 (Figure 2) shows that this complex is formed cleanly and has an isomer shift of $0.46(1) \mathrm{mm} / \mathrm{s}$, consistent with a high-spin $\mathrm{Fe}(\mathrm{III})$ center. The relatively small quadrupole splitting of $0.76(1) \mathrm{mm} / \mathrm{s}$ is similarly consistent with a high-spin $\mathrm{Fe}$ (III) center. X-ray absorption spectroscopy collected on $\mathbf{1}$ and $\mathbf{3}$ shows an increase in the K-edge energy consistent with an increase in the oxidation state from an $\mathrm{Fe}$ (II) complex to an $\mathrm{Fe}$ (III) complex (see Figure S28). Numerous unsuccessful attempts were made to grow crystals suitable for X-ray diffraction at $-78{ }^{\circ} \mathrm{C}$, and the EXAFS region of $\mathbf{3}$ is unfortunately too noisy for reliable structural determination.

Two likely high-spin $\mathrm{Fe}(\mathrm{III})$ products of the reaction of $\mathbf{1}$ with $\mathrm{O}_{2}$ are an $\mathrm{Fe}(\mathrm{III})$-superoxo complex featuring a ${ }^{t \mathrm{Bu} \text {,- }}$ ${ }^{\mathrm{Tol}} \mathrm{DHP}-\mathrm{H}_{2}$ ligand or an $\mathrm{Fe}(\mathrm{III})$-hydroperoxo complex, where an $\mathrm{H}$-atom has been abstracted by a putative superoxo precursor to form the ${ }^{t \mathrm{Bu}, \mathrm{Tol}} \mathrm{DHP}-\mathrm{H}^{\bullet}$ ligand radical and a hydroperoxo ligand; these structures are shown in Scheme 2. Both complexes would be expected to have an overall spin of $S$ $=2$ assuming an $S=5 / 2 \mathrm{Fe}$ (III) center coupled antiferromagnetically to a ligand based radical of the superoxo ligand or the ${ }^{t \mathrm{Bu}, \mathrm{Tol}} \mathrm{DHP}-\mathrm{H}^{\bullet}$ ligand, respectively. EPR spectroscopy in parallel mode of 3 as a $15 \mathrm{mM}$ frozen solution at $15 \mathrm{~K}$ in toluene was collected to test for this hypothesized spin-state. The parallel mode X-band EPR spectrum of 3 shows a feature at $g=10.6$ consistent with an $S=2$ species, as would be expected for either of these assignments (see Figure S23).

Vibrational spectroscopy was then used to look for the putative $\mathrm{O}-\mathrm{O}, \mathrm{O}-\mathrm{H}$, and $\mathrm{N}-\mathrm{H}$ stretches for an $\mathrm{Fe}(\mathrm{III})$ superoxo complex or an $\mathrm{Fe}$ (III)-hydroperoxo complex using isotopic labeling studies. Raman spectroscopy was performed

UV-visible spectroscopy and then compared to the spectrum of 3 formed in the presence of excess $\mathrm{O}_{2}$ (see Figure S12). 
Scheme 2. Reaction of 1 with $\mathrm{O}_{2}{ }^{a}$

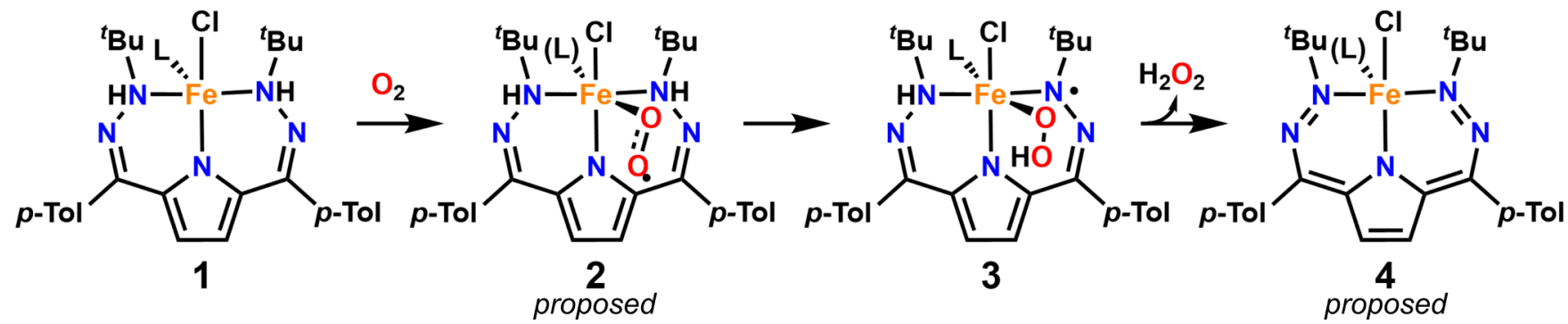

${ }^{a}$ Note: $\mathbf{2}$ and $\mathbf{4}$ are only proposed intermediates and are only present as mixtures.

on 3 generated from 1 in the solid state at $-44{ }^{\circ} \mathrm{C}$ and collected at $77 \mathrm{~K}$. Data were collected with a $532 \mathrm{~nm}$ laser on $10 \%$ power (Figure 3A; see SI experimental). These data show a peak at $890 \mathrm{~cm}^{-1}$ in the spectrum collected with ${ }^{16} \mathrm{O}_{2}$ that shifts to $850 \mathrm{~cm}^{-1}$ in the spectrum collected with ${ }^{18} \mathrm{O}_{2}$. This shift is similar to the $50 \mathrm{~cm}^{-1}$ shift that would be expected for an $\mathrm{O}-\mathrm{O}$ stretching frequency assuming a simple harmonic oscillator. The slight deviation from theory may arise from overlapping vibrations as well as coupling with other vibrational modes.

In addition to Raman data, similar features are seen by IR spectroscopy. Intermediate $\mathbf{3}$ was generated as a solution in chlorobenzene, as a thin film on $\mathrm{KBr}$ plates, and as a solid in a $\mathrm{KBr}$ matrix. Although these IR measurements were conducted at RT rather than below $-40{ }^{\circ} \mathrm{C}$, a comparison of the ${ }^{16} \mathrm{O}_{2}$ and ${ }^{18} \mathrm{O}_{2}$ spectra across all these techniques reveals weak and broad signals which are consistent with those seen by Raman spectroscopy. There is a disappearance of a feature at $\sim 885$ $\mathrm{cm}^{-1}$ and the growth of a new feature at $\sim 845 \mathrm{~cm}^{-1}$ in the ${ }^{16} \mathrm{O}$ versus the ${ }^{18} \mathrm{O}$ data (see Figures S17-S22).

These vibrations in both the Raman and IR data more closely align with an $\mathrm{O}-\mathrm{O}$ stretch for an $\mathrm{Fe}(\mathrm{III})$-hydroperoxo assignment rather than with an $\mathrm{Fe}$ (III)-superoxo complex. A superoxo complex would be expected to have an $\mathrm{O}-\mathrm{O}$ stretch between 1000 and $1300 \mathrm{~cm}^{-1} \cdot{ }^{76}$ The observed $\mathrm{O}-\mathrm{O}$ stretching frequency compares favorably with related $\mathrm{Fe}$ hydroperoxo complexes. ${ }^{41,42,77,43-50}$

Additionally, two features are seen by IR spectroscopy at 3420 and $3230 \mathrm{~cm}^{-1}$, which could be assigned either as two $\mathrm{N}-\mathrm{H}$ stretches or as an $\mathrm{N}-\mathrm{H}$ and $\mathrm{O}-\mathrm{H}$ stretch for an $\mathrm{Fe}(\mathrm{III})$ superoxo and $\mathrm{Fe}$ (III)-hydroperoxo, respectively (Figure 3B). Given the much higher intensity of the feature at $3420 \mathrm{~cm}^{-1}$ relative to the feature at $3230 \mathrm{~cm}^{-1}$, and the dramatically higher stretching frequency for one of these features versus $\nu_{\mathrm{NH}}$ in 1 , the most reasonable conclusion is that these stretches do not both arise from $\mathrm{N}-\mathrm{H}$ moieties but rather are an $\mathrm{N}-\mathrm{H}$ and an $\mathrm{O}-\mathrm{H}$ stretch, consistent with an $\mathrm{Fe}(\mathrm{III})$-hydroperoxo complex. IR spectra of this mixture were collected using a deuterated version of 1 , where the metalation was completed using $81 \%$ enriched ${ }^{t \mathrm{Bu}, \mathrm{Tol}} \mathrm{DHP}-\mathrm{D}_{2} \cdot 2 \mathrm{DCl}$ ligand salt. When reacted with $\mathrm{O}_{2}$, IR spectroscopy of this reaction using the deuterated version of 1 shows growth of a feature at 2546 $\mathrm{cm}^{-1}$, which is consistent with an $\mathrm{O}-\mathrm{H}$ to $\mathrm{O}-\mathrm{D}$ shift. Similarly, the feature at $3230 \mathrm{~cm}^{-1}$ largely disappears when $\mathbf{1}$ is enriched with deuterium and a broad feature grows in at 2375-2404 $\mathrm{cm}^{-1}$. Both shifts are consistent with the expected shift assuming a perfect harmonic oscillator model. Together, these vibrational data are most consistent with an $\mathrm{Fe}$ (III)-
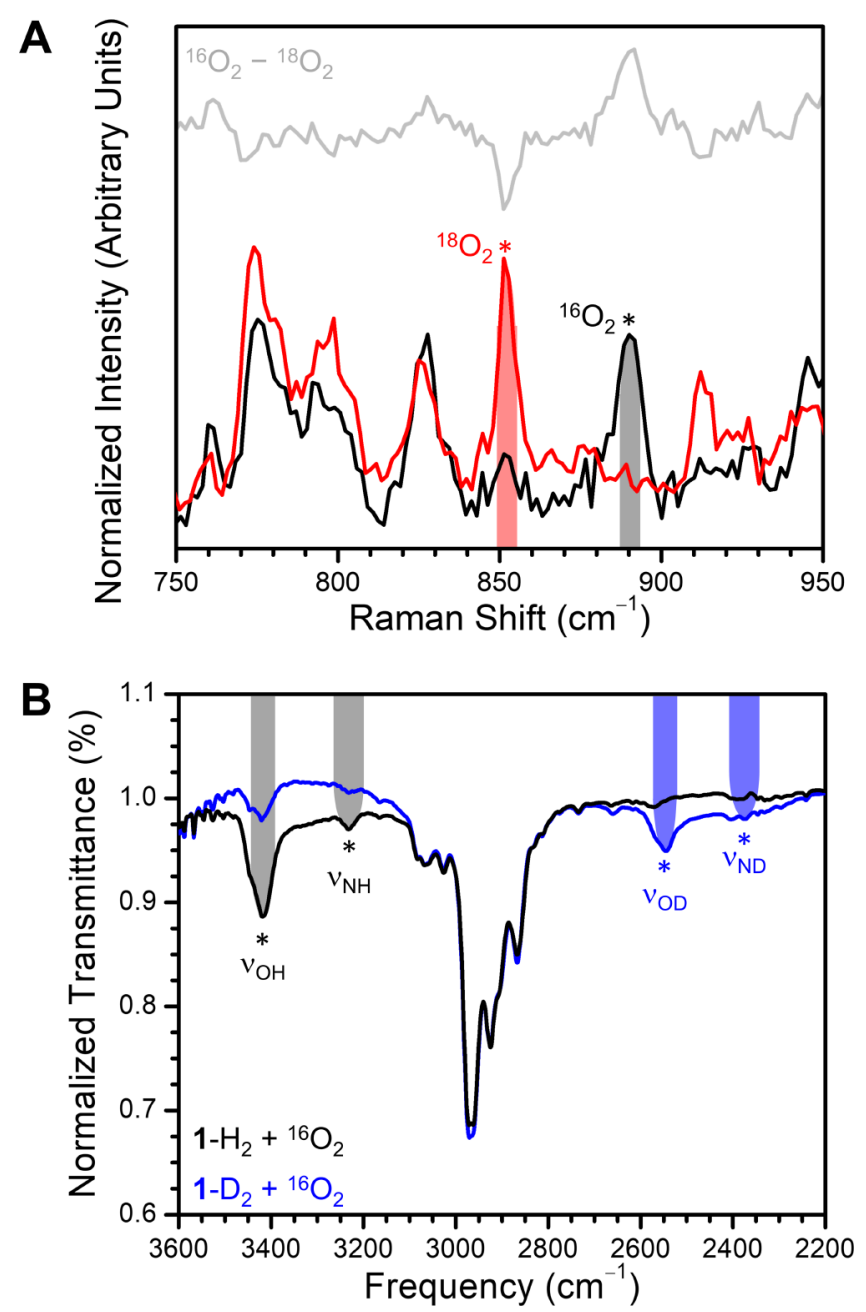

Figure 3. (A) Variable isotope Raman spectra of the reaction of $\mathbf{1}$ in the solid state with $\mathrm{O}_{2}$ at $-40{ }^{\circ} \mathrm{C}$ to form 3 . The reaction with ${ }^{16} \mathrm{O}_{2}$ vs ${ }^{18} \mathrm{O}_{2}$ are shown in the peroxo stretching region.The difference spectrum is shown above the normalized data for ${ }^{16} \mathrm{O}_{2}$ and ${ }^{18} \mathrm{O}_{2}$. (B) Variable isotope IR spectra of the reaction of $\mathbf{1}$ with $\mathrm{O}_{2}$ at RT to form 3. Proteo- vs deutero-1 ( $83 \%$ enriched) reacted with ${ }^{16} \mathrm{O}_{2}$ collected as concentrated solutions in chlorobenzene.

hydroperoxo complex rather than an $\mathrm{Fe}(\mathrm{III})$-superoxo complex.

Computational Analysis of 3. All of the experimental data on 3 are consistent with the assignment of an Fe(III)hydroperoxo complex generated from intramolecular activation of $\mathrm{O}_{2}$. However, in the absence of direct structural data, we wanted to additionally support this assignment with a 


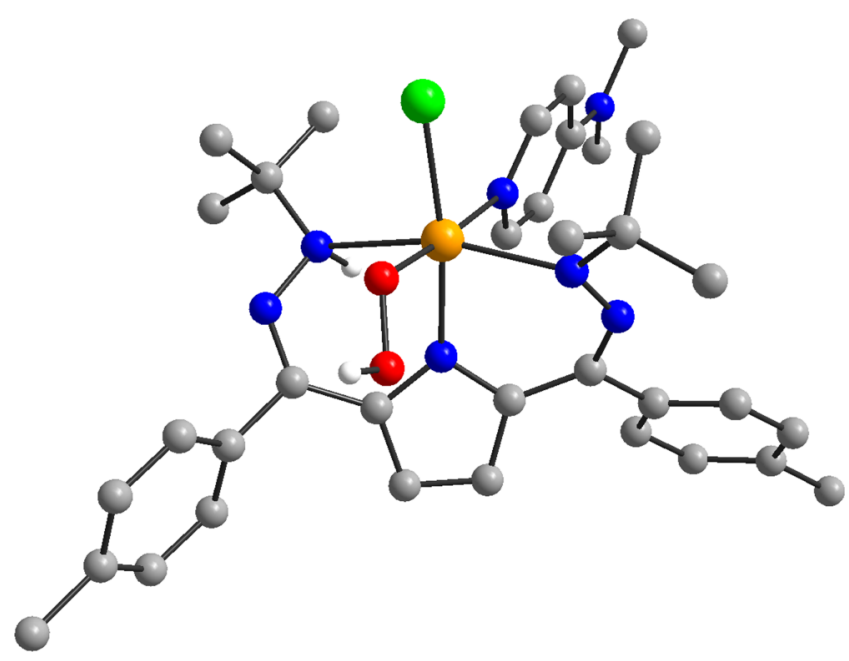

Figure 4. DFT computed structure of 3 with $\mathrm{Fe}$ in orange, $\mathrm{C}$ in gray, $\mathrm{N}$ in blue, $\mathrm{O}$ in red, $\mathrm{Cl}$ in green, and selected H's in white.

computational treatment. The proposed assignment of 3 was therefore investigated using density functional theory (DFT) calculations. Geometry optimizations and frequency calculations for both the putative $\mathrm{Fe}$ (III)-superoxo and $\mathrm{Fe}$ (III)hydroperoxo complexes were done using the B3P hybrid functional. $^{78-80}$ The predicted structure of 3 is shown in Figure 4 and features bond lengths of 1.89 and $1.41 \AA$ for the $\mathrm{Fe}-\mathrm{O}$ and $\mathrm{O}-\mathrm{O}$ bonds, respectively, as expected for an $\mathrm{Fe}(\mathrm{III})$-hydroperoxo complex. The computed spin density is also consistent with a high-spin $\mathrm{Fe}$ (III) center antiferromagnetically coupled to a ligand radical (see Figure S34). Finally, the DFT-predicted vibrational frequencies for 3 also agree well with those observed experimentally (see Table S15).

A single point calculation was then run using the optimized geometries to predict the Mössbauer isomer shift and quadrupole splitting parameters using the TPSSh functional, with a basis set of $\mathrm{CP}(\mathrm{PPP})$ on $\mathrm{Fe}$, and an increased polarization on all other atoms except $\mathrm{H}^{78-81}$ These calculations suggest that an $\mathrm{Fe}$ (III)-hydroperoxo is the best assignment for the Mössbauer data. The theoretical isomer shift of $0.47 \mathrm{~mm} / \mathrm{s}$ and quadrupole splitting of $-0.85 \mathrm{~mm} / \mathrm{s}$ are in good agreement with the experimentally determined values of $0.46(1) \mathrm{mm} / \mathrm{s}$ and $0.76(1) \mathrm{mm} / \mathrm{s}$. Conversely, the values predicted for an $\mathrm{Fe}(\mathrm{III})$-superoxo assignment match much more poorly, with a preicted isomer shift of $0.61 \mathrm{~mm} / \mathrm{s}$ and quadrupole splitting of $1.07 \mathrm{~mm} / \mathrm{s}$.

Time dependent DFT (TD-DFT) was also run to calculate the theoretical UV-visible spectrum of the proposed $\mathrm{Fe}$ (III)superoxo and $\mathrm{Fe}$ (III)-hydroperoxo complexes using the PBE0 functional on the previously optimized geometries. ${ }^{78-80,82}$ The theoretical spectrum for a 6-coordinate $\mathrm{Fe}$ (III)-hydroperoxo complex with a ligand based radical was found to be a good fit for the experimental spectrum while the $\mathrm{Fe}(\mathrm{III})$-superoxo complex was not (see Figure S35), further suggesting that the correct assignment for 3 is that of an $\mathrm{Fe}$ (III)-hydroperoxo with a ligand based radical on ${ }^{t \mathrm{Bu}, \mathrm{Tol}} \mathrm{DHP}-\mathrm{H}^{\bullet}$. In addition to this computational match, we note that the experimental UVvisible data for 3 is consistent with literature UV-visible data where a strong feature grows in at $\sim 500 \mathrm{~nm}$ upon the formation of an $\mathrm{Fe}$ (III)-hydroperoxo, which arises from ligandto-metal charge transfer (LMCT) from the hydroperoxo ligand to the Fe-center. ${ }^{41-45,50,53,83,84}$ TD-DFT of the Fe(III)- hydroperoxo with a ligand based radical is also consistent with LMCT transitions contributing to the peak at $518 \mathrm{~nm}$ (see Figure S36). Furthermore, TD-DFT suggests that the second feature in these data at $714 \mathrm{~nm}$ is likely due to a MLCT between the Fe-center and the ligand based radical of the ${ }^{t \mathrm{Bu}, \mathrm{Tol}}{ }^{\mathrm{DHP}}-\mathrm{H}^{\bullet}$ ligand (see Figure S36). This presence of a low

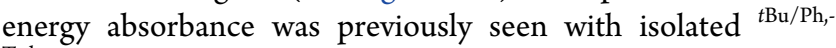
${ }^{\mathrm{T} o l} \mathrm{DHP}$ ligand radicals on $\mathrm{Ni}$ and $\mathrm{Fe}$ centers, further supporting the assignment of $\mathbf{3}$ with a ligand based radical on ${ }^{\mathrm{BBu}, \mathrm{Tol}} \mathrm{DHP}-\mathrm{H}^{\bullet}$ (Scheme 2). ${ }^{53,69,85}$

Evolution of 3 Upon Warming. As mentioned above, upon being warmed, 3 reacts further to form a new complex, 4, by UV-visible spectroscopy (Figure 1). Unfortunately, $\mathbf{4}$ is not stable at any temperature that it can be produced at and will slowly bleach over time, making characterization challenging (see Figure S7). One possible assignment for 4 is that of an $\mathrm{Fe}(\mathrm{IV})$-oxo which forms by abstracting a second $\mathrm{H}$-atom from the ${ }^{t \mathrm{Bu}, \mathrm{Tol}} \mathrm{DHP}-\mathrm{H}^{\bullet}$ ligand and releasing water. This would result in an oxidized ${ }^{t \mathrm{Bu}, \mathrm{Tol}} \mathrm{DHP}$ ligand in addition to a highly oxidized $\mathrm{Fe}(\mathrm{IV})$ center, mimicking the reactivity of cytochrome $\mathrm{P} 450$. Another possibility is that when the second $\mathrm{H}$ atom is abstracted from the ligand, $\mathrm{H}_{2} \mathrm{O}_{2}$ is released and an $\mathrm{Fe}(\mathrm{II})$ complex featuring an oxidized ${ }^{\mathrm{BBu}, \mathrm{Tol}} \mathrm{DHP}$ ligand is formed. Allowing 3 to warm such that 4 could evolve allowed us to collect a Mössbauer spectra of a mixture of $\mathbf{3}$ and 4 . This shows an isomer shift of $0.38(1) \mathrm{mm} / \mathrm{s}$ and a quadrupole splitting of $1.32(2) \mathrm{mm} / \mathrm{s}$ for 4 , which best aligns with a low spin $\mathrm{Fe}(\mathrm{II})$ center or an $\mathrm{Fe}(\mathrm{III})$ center (see Figure S27). ${ }^{86}$ This observation argues against an $\mathrm{Fe}(\mathrm{IV})$ assignment and suggests that loss of $\mathrm{H}_{2} \mathrm{O}_{2}$ to generate a $\mathrm{Fe}$ (II) center with an oxidized ligand is a more reasonable pathway. To test the feasibility of an $\mathrm{Fe}$ (II) product with an oxidized DHP ligand, $\mathrm{TEMPO}^{\bullet}$ was added to solution of $\mathbf{1}$ to putatively remove two $\mathrm{H}$-atoms. When this experiment is carried out, UV-visible absorbances matching those seen for $\mathbf{4}$ grow in, suggesting that the tentative assignment of $\mathbf{4}$ as $\mathrm{Fe}\left({ }^{t \mathrm{Bu}, \mathrm{Tol}} \mathrm{DHP}\right)(\mathrm{DMAP}) \mathrm{Cl}$ is reasonable (see Figure S13). While circumstantial, these data suggest that the net reactivity of this system may be to release $\mathrm{H}_{2} \mathrm{O}_{2}$ when reacted with molecular oxygen (Scheme 2).

To determine if $\mathrm{H}_{2} \mathrm{O}_{2}$ was formed from the reaction of 1 with $\mathrm{O}_{2}$, a chemical test was conducted. It has been reported that $\mathrm{H}_{2} \mathrm{O}_{2}$ reacts selectively and stoichiometrically with 1,3diphenylisobenzofuran (DPBF) to form 9-hydroxyanthracen$10(9 \mathrm{H})$-one. When DPBF is reacted with other peroxides, 1,2dibenzoylbenzene will form instead. ${ }^{87}$ As such, this is an excellent method for probing if $\mathrm{H}_{2} \mathrm{O}_{2}$ specifically is produced as a byproduct. The reaction of $\mathbf{1}$ with $\mathrm{O}_{2}$ was conducted, the solution was sparged with $\mathrm{N}_{2}$, then 10.2 equiv of DPBF were added. A small amount of 9-hydroxyanthracen-10(9H)-one was reproducibly observed by gas chromatography-mass spectrometry (GC-MS, see Figure S42), as would be expected if $\mathrm{H}_{2} \mathrm{O}_{2}$ had been produced. While this test is indirect, the selective formation of 9-hydroxyanthracen-10(9H)-one is strong evidence for the presence of $\mathrm{H}_{2} \mathrm{O}_{2}$. This result is also consistent with decomposition of 3 by loss of $\mathrm{H}_{2} \mathrm{O}_{2}$ to generate 4, as depicted in Scheme 2. It is noteworthy that this system appears to generate $\mathrm{H}_{2} \mathrm{O}_{2}$ instead of an $\mathrm{Fe}(\mathrm{IV})$ oxo intermediate and water. This mechanistic bifurcation is tightly regulated in biological systems, and we suspect that the selectivity for $\mathrm{H}_{2} \mathrm{O}_{2}$ formation in this synthetic system is the result of the orientation of the hydrogens in the secondary coordination sphere. Related H-bonding effects have been noted recently in $\mathrm{Cu}$ systems. ${ }^{18,19,88}$ 
Oxidative Reactivity. Encouraged by the biomimetic nature of this system, oxidative reactivity in the presence of molecular oxygen was investigated. By low temperature UVvisible spectroscopy, 3 was found to react with 10 equiv of $\mathrm{PPh}_{3}$ slowly at $-40{ }^{\circ} \mathrm{C}$. We speculate that 3 may perform Oatom transfer to $\mathrm{PPh}_{3}$ and form $\mathrm{OPPh}_{3}$, presumably via nucleophilic attack by the phosphine onto the electrophilic hydroperoxocomplex. When this reaction was conducted in a JYoung tube and monitored by ${ }^{31} \mathrm{P} \mathrm{NMR}$ at room temperature, 1 equiv of $\mathrm{OPPh}_{3}$ was observed (see Figure S5). When the reaction was done in the presence of ${ }^{18} \mathrm{O}_{2}$, enrichment of the isotopically labeled $\mathrm{OPPh}_{3}$ product was observed by GC-MS analysis demonstrating that the source of the oxidizing equivalent is the added $\mathrm{O}_{2}$ (see Figure S37). The formation of only 1 equiv of $\mathrm{OPPh}_{3}$ per equivalent of $\mathbf{1}$ is significant. This means that only one of the O-equivalents from $\mathrm{O}_{2}$ is ultimately being accessed for oxidative reactivity, consistent with the proposed steps shown in Scheme 2.

The reactivity of 3 and $\mathbf{4}$ toward $\mathrm{H}$-atom abstraction was also investigated with diphenylhydrazine (DPH), dihydroanthracene (DHA), and 1,4-cyclohexadiene (CHD). Complex 3 was found to react with $\mathrm{DPH}$ at $-40{ }^{\circ} \mathrm{C}$ by $\mathrm{UV}$-visible spectroscopy, but not DHA or CHD, suggesting that 3 can abstract $\mathrm{H}$-atoms from a relatively weak $\mathrm{N}-\mathrm{H}$ bond but not stronger $\mathrm{C}-\mathrm{H}$ bonds at low temperature. Conversely, experiments conducted at room temperature show both $\mathrm{C}-$ $\mathrm{H}$ activation and oxygenation products for DHA, toluene, and $\mathrm{PPh}_{3}$ when analyzed by GC-MS (see Figures S39-41). Overall, the observed reactivity is consistent with oxidation occurring from either 3 , from an oxidizing byproduct such as hydroxyl radical or $\mathrm{H}_{2} \mathrm{O}_{2}$ as shown in Scheme 2, or as some Feactivated $\mathrm{H}_{2} \mathrm{O}_{2}$ complex (i.e., an Fe-oxo complex) at temperatures above $-40{ }^{\circ} \mathrm{C}$. The convoluted nature of this reaction mixture makes it difficult to discern the exact nature of the active oxidant at these higher temperatures where oxygenated products are observed.

\section{CONCLUSIONS}

In this study, we have directly synthesized an $\mathrm{Fe}$ (III)hydroperoxo intermediate from an $\mathrm{Fe}$ (II) complex featuring pendant $\mathrm{H}$-atom equivalents and $\mathrm{O}_{2}$. This unusual $\mathrm{Fe}(\mathrm{III})$ hydroperoxo complex with a ${ }^{t \mathrm{Bu}, \mathrm{Tol}} \mathrm{DHP}-\mathrm{H}^{\bullet}$ ligand based radical was characterized by a variety of spectroscopic and computational techniques in addition to kinetic studies. This intermediate is thermally unstable, and we propose decomposition to a terminal $\mathrm{Fe}(\mathrm{II})$ product with release of $\mathrm{H}_{2} \mathrm{O}_{2}$. This system also displays oxidative reactivity toward a variety of substrates. This reactivity can stem either directly from the hydroperoxo intermediate or potentially from the $\mathrm{H}_{2} \mathrm{O}_{2}$ byproduct. This study demonstrates that the combination of redox-active ligands and pendant $\mathrm{H}$ donors allows for the unimolecular activation of $\mathrm{O}_{2}$ via controlled movement of protons and electrons from the secondary coordination sphere. Furthermore, this reactivity is reminiscent of biology's strategy of using redox-active cofactors, $\mathrm{Fe}$ centers, and pendant protons shuttled from nearby amino acids or active site water molecules in enzymes to mediate challenging reactivity with $\mathrm{O}_{2}$.

\section{EXPERIMENTAL SECTION}

General Methods. All chemicals were purchased from commercial suppliers and used without further purification. All manipulations were carried out under an atmosphere of $\mathrm{N}_{2}$ using standard Schlenk and glovebox techniques. Glassware was dried at $180{ }^{\circ} \mathrm{C}$ for a minimum of $2 \mathrm{~h}$ and cooled under a vacuum prior to use. Solvents were dried on a solvent purification system from Pure Process Technologies and stored over $4 \AA$ molecular sieves under $\mathrm{N}_{2}$. Tetrahydrofuran (THF) was stirred over $\mathrm{NaK}$ alloy and run through an additional alumina column prior to use to ensure dryness. Solvents were tested for $\mathrm{H}_{2} \mathrm{O}$ and $\mathrm{O}_{2}$ using a standard solution of sodiumbenzophenone ketyl radical anion. $\mathrm{CD}_{3} \mathrm{CN}, \mathrm{C}_{6} \mathrm{D}_{6}$, and $d_{8}$-toluene were dried over $4 \AA$ molecular sieves under $\mathrm{N}_{2}$.

${ }^{1} \mathrm{H}$ and ${ }^{31} \mathrm{P}\left\{{ }^{1} \mathrm{H}\right\}$ NMR spectra were recorded on Bruker DRX 400 or 500 spectrometers. Chemical shifts are reported in ppm units referenced to residual solvent resonances for ${ }^{1} \mathrm{H}$ and ${ }^{31} \mathrm{H}\left\{{ }^{1} \mathrm{H}\right\}$ spectra. UV-vis spectra were recorded on a Bruker Evolution 300 spectrometer and analyzed using VisionPro software. IR spectra were obtained on a Bruker Tensor II spectrometer with the OPUS software suite. All IR samples were prepared nujol mulls or collected between $\mathrm{KBr}$ plates. EPR spectra were recorded on an Elexsys E500 Spectrometer with an Oxford ESR $900 \mathrm{X}$-band cryostat and a Bruker Cold-Edge Stinger. EPR data was analyzed using SpinCount. Single crystal X-ray diffraction data were collected in-house using Bruker D8 Venture diffractometer equipped with Mo microfocus X-ray tube $(\lambda=$ $0.71073 \AA)$.

$\mathrm{X}$-ray near-edge absorption spectra (XANES) were employed to probe the local environment of Fe. Powder samples were prepared by material grinding finely. A Teflon window was sealed on one side with Kapton tape, and powder was then transferred to the inside of this ring before it was compacted with a Teflon rod and the remaining face sealed with Kapton tape. After transfer of the material, the window was sealed with Kapton tape. All sample preparation was performed under an inert atmosphere. Frozen solution samples were prepared by making a concentrated solution in THF of the starting material, removing the sample from the glovebox, cooling the sample in a bath, then reacting the sample with $\mathrm{O}_{2}$ by syringing the gas into the sample and bubbling it through. After being allowed to react, the sample was exposed to air and a precooled pipet was used to transfer the solution to a Teflon window lined on one side with Kapton tape. The solution was frozen using liquid nitrogen and then stored in liquid nitrogen until collection. Data were acquired at the Advanced Photon Source at Argonne National Laboratories with a bending magnet source with ring energy at $7.00 \mathrm{GeV}$. Fe K-edge data were acquired at the MRCAT 10-BM beamline. The incident, transmitted and reference $\mathrm{X}$ ray intensities were monitored using gas ionization chambers. A metallic iron foil standard was used as a reference for energy calibration and was measured simultaneously with experimental samples. X-ray absorption spectra were collected at room temperature. Data collected was processed using the Demeter software suite.

Zero-field ${ }^{57} \mathrm{Fe}$ Mössbauer spectra were obtained at $80 \mathrm{~K}$ using a ${ }^{57} \mathrm{Co}$ /rhodium source. Samples were prepared in an MBraun nitrogen glovebox. A typical powder sample containing approximately $60 \mathrm{mg}$ of compounds was suspended in a plastic cap. Another cap with a slightly smaller diameter was squeezed into the previous sample cap to completely encapsulate the solid sample mixture. Frozen solution samples were prepared as concentrated solutions of ${ }^{57} \mathrm{Fe}$ enriched $\mathbf{1}$ in toluene in the glovebox, removed from the glovebox under nitrogen, placed in a cold bath of $-78{ }^{\circ} \mathrm{C}$ or $-40{ }^{\circ} \mathrm{C}$, and reacted with an excess of $\mathrm{O}_{2}$ which was bubbled through the solution. After reacting for the desired amount of time, the solution was exposed to air and pipetted with a precooled pipet into a plastic cap and frozen in liquid nitrogen. Another cap with a slightly smaller diameter was squeezed into the previous sample cap to completely encapsulate the frozen sample mixture. All spectra were analyzed using the WMOSS Mössbauer Spectral Analysis Software. Note that the accuracy of the fit parameters may be overestimated as the error in the Fe foil calibration is $0.01 \mathrm{~mm} / \mathrm{s}$.

$\mathrm{Fe}\left({ }^{\mathrm{tBu}, \mathrm{Tol}} \mathrm{DHP}-\mathrm{H}_{2}\right)(\mathrm{DMAP}) \mathrm{Cl}(1)$. In a $20 \mathrm{~mL}$ vial in the glovebox, 3 $\mathrm{mL}$ of THF was added to $\mathrm{FeCl}_{2}(24 \mathrm{mg}, 1 \mathrm{eq}, 0.19 \mathrm{mmol})$. A solution of dimethylaminopyrrole ( $24 \mathrm{mg}$, 1 eq., $0.19 \mathrm{mmol}$ ) in $2 \mathrm{~mL}$ of THF was added to the $\mathrm{FeCl}_{2}$ suspension and stirred until a white suspension formed. The $\left[{ }^{\mathrm{tBu}, \mathrm{Tol}} \mathrm{DHP}-\mathrm{H}_{4}\right][\mathrm{Cl}]_{2}$ ligand salt ${ }^{70}(100 \mathrm{mg}, 1$ eq., $0.2 \mathrm{mmol}$ ) was dissolved in $5 \mathrm{~mL}$ of THF and added to the $\mathrm{Fe}$ 
solution to form a bright yellow suspension in a yellow solution. After being stirred for $10 \mathrm{~min}$, KHMDS (104 mg, 2.7 eq., $0.521 \mathrm{mmol}$ ) dissolved in $1 \mathrm{~mL}$ THF was added dropwise with stirring. The solution turned from orange with a yellow precipitate, to colorless with a white precipitate, to colorless with no precipitate, to a deep orange-brown. Immediately after the addition of KHMDS and this sequence, the reaction mixture was condensed under a vacuum. The resulting brown solid was taken up in toluene, filtered, and condensed under a vacuum, then washed with petroleum ether $(10 \mathrm{~mL})$. After being dried, the pure bulk product was obtained as a pale orange solid. Yield: $90 \mathrm{mg}, 71 \%$. Single crystals suitable for XRD were grown via vapor diffusion of petroleum ether into a concentrated solution of product in toluene overnight at room temperature. ${ }^{1} \mathrm{H}$ NMR (400 $\mathrm{MHz}, \mathrm{CD}_{3} \mathrm{CN}, \mathrm{RT}$ ): $\delta=29.2$ (bs), 10.5 (bs), 8.6 (bs), 6.0 (bs), 5.7 (bs), -3.4 (bs). Magnetic Susceptibility: Evans' Method $\left(\mathrm{C}_{6} \mathrm{D}_{6}\right.$, RT, $\left.\mu_{\mathrm{B}}\right): \mu_{\text {eff }}=5.0$; IR (Nujol mull between KBr plates, $\left.\mathrm{cm}^{-1}\right): 3180(\mathrm{~N}-$ $\mathrm{H}, \mathrm{w}), 3170(\mathrm{~N}-\mathrm{H}, \mathrm{w}), 1641$ (s). Mössbauer $(80 \mathrm{~K}, \mathrm{~mm} / \mathrm{s}) \delta=$ $1.090(6) ; \Delta E_{\mathrm{Q}}=2.367(9)$. UV-vis, $\mathrm{nm}$ in toluene, $\left(\varepsilon, \mathrm{M}^{-1} \mathrm{~cm}^{-1}\right)$ : 516 (286). Anal. Calc. C, 64.07; H, 7.07; N, 14.94; Found: C, 64.65; H, 7.40; N, 14.03.

Reactivity with $\mathrm{PPh}_{3}, \mathrm{DHA}$, and Diphenylhydrazene (DPH). A $0.35 \mathrm{mM}$ solution of $\mathbf{1}$ in toluene was prepared in the glovebox in an airtight cuvette with a septa. After the solution was cooled to -40 ${ }^{\circ} \mathrm{C}, 0.5 \mathrm{~mL}$ of $\mathrm{O}_{2}$ was added via syringe, and the mixture was allowed to react until the absorbances for 3 had fully grown in. Then, 10 equiv of $\mathrm{PPh}_{3}$ were added as a solution in toluene via syringe and monitored over time with UV-visible spectroscopy. This same procedure was followed for DHA (10 equiv to a $0.35 \mathrm{mM}$ solution of $\mathbf{1}$ ) and DPH (20 equiv to a $0.42 \mathrm{mM}$ solution of 1 ) and neat 1,4-cyclohexadiene (CHD) (20 equiv to a $0.42 \mathrm{mM}$ solution of 1 ). This procedure was repeated with room temperature solutions of 1 with 20 equiv of $\mathrm{PPh}_{3}$ and DHA, and 10 equiv of DPH, respectively. The substrate was added $10 \mathrm{~min}$ after reacting with $6 \mathrm{~mL}$ of $\mathrm{O}_{2}$ to ensure that 3 had fully formed. When the reaction had finished bleaching, these reactions were analyzed by GC-MS. For CHD, 3 was generated cold, CHD was added, then the reaction was warmed and allowed to stir overnight before being analyzed by GC-MS.

Reactivity with $\mathrm{PPh}_{3}$ by NMR. An NMR solution was prepared with $5 \mathrm{mg}$ of 1 in toluene $\left(\mathrm{C}_{7} \mathrm{H}_{8}\right)$ with a septa NMR cap. This was then reacted with 10 equiv of $\mathrm{PPh}_{3}$ (added via syringe). Then, $6 \mathrm{~mL}$ of $\mathrm{O}_{2}$ was bubbled through the solution using a syringe at room temperature. This was allowed to react overnight at room temperature and then analyzed by ${ }^{31} \mathrm{P}\left\{{ }^{1} \mathrm{H}\right\} \mathrm{NMR}$.

Reactivity with Diphenylisobenzofuran (DPBF). In a $20 \mathrm{~mL}$ glass vial, 1 (14 mg, 1 equiv) was dissolved in toluene $(2 \mathrm{~mL})$ and sealed with a septa in the nitrogen glovebox. This was removed from the glovebox; $11 \mathrm{~mL}$ of $\mathrm{O}_{2}$ was added to the solution and the mixture was allowed to react for $15 \mathrm{~min}$ at room temperature. This was purged with $11 \mathrm{~mL} \mathrm{~N} \mathrm{~N}_{2}$; DPBF (63 mg, 10.2 equiv) was added in the glovebox, and the reaction mixture was allowed to stir overnight. The solution was then filtered and analyzed by GC-MS.

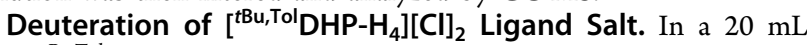
vial, $\left.{ }^{[\mathrm{Bu}, \mathrm{Tol}} \mathrm{DHP}-\mathrm{H}_{4}\right][\mathrm{Cl}]_{2}$ ligand salt $(100 \mathrm{mg}, 1$ eq., $0.19 \mathrm{mmol})$ was dissolved in THF $(10 \mathrm{~mL})$. This mixture was cooled in a $-35{ }^{\circ} \mathrm{C}$ freezer for $20 \mathrm{~min}$. The solution was removed from the freezer and $\mathrm{nBuLi}(0.39 \mathrm{~mL}$ of a $2.5 \mathrm{M}$ solution in diethyl ether, 5 eq., 0.96 $\mathrm{mmol}$ ) was added dropwise with stirring at room temperature, causing the reaction to turn a deep red. This solution was allowed to stir for $5 \mathrm{~min}$ after which it was slowly warmed to room temperature, then $\mathrm{DCl}$ or $d_{4}$-acetic acid (5 eq., $0.96 \mathrm{mmol}$ ) was added with stirring, causing the reaction to lighten to a golden yellow-orange. The reaction was condensed under a vacuum, taken up in toluene and filtered to remove $\mathrm{LiCl}$ or $\mathrm{LiOAc}$, then recondensed. The resulting oil was taken up in THF $(1 \mathrm{~mL})$ and recrystallized via layer recrystallization with petroleum ether in the glovebox overnight. Yield: 50\%. Percent enrichment by ${ }^{1} \mathrm{H}$ NMR: $81(\mathrm{DCl})$ or $93\left(d_{4^{-}}\right.$ acetic acid).

Preparation of IR Samples of 3. Concentrated solution in chlorobenzene. Complex 1 (10 mg) was placed in a $20 \mathrm{~mL}$ vial with a stir bar and $0.2 \mathrm{~mL}$ of chlorobenzene. A septa was used to seal the vial. This was removed from the glovebox, and $\mathrm{O}_{2}(0.39 \mathrm{~mL}, 1$ equiv) was added via syringe, with the gas bubbled through the reaction mixture. This was immediately syringed into a solution cell IR, and a spectrum was collected.

Thin film on a $\mathrm{KBr}$ plate. Complex $\mathbf{1}(10 \mathrm{mg})$ was placed in a 20 $\mathrm{mL}$ vial with a stir bar and $0.2 \mathrm{~mL}$ of DCM. A septa was used to seal the vial. This was removed from the glovebox, and $\mathrm{O}_{2}(0.39 \mathrm{~mL}, 1$ equiv) was added via syringe, with the gas bubbled through the reaction mixture. Using a syringe, the reaction mixture was removed from the vial, then one drop was placed on a $\mathrm{KBr}$ plate. Once DCM had evaporated, a second $\mathrm{KBr}$ plate was placed on top and a spectrum was collected.

Reaction in the solid state. Complex $\mathbf{1}(5 \mathrm{mg})$ was placed in a 20 $\mathrm{mL}$ vial with a stir bar and dry $\mathrm{KBr}$ powder $(400 \mathrm{mg})$, mixed, and ground into a fine powder. A septa was used to seal the vial. This was removed from the glovebox, and an excess of $\mathrm{O}_{2}(3 \mathrm{~mL})$ was added to the vial headspace. This was allowed to stir at room temperature for 1 h. The septa was removed; the mixture in $\mathrm{KBr}$ was used to form a $\mathrm{KBr}$ pellet, and a spectrum was collected.

Preparation of Raman Samples of 3. Complex 1 (7.5-14.5 $\mathrm{mg}$ ) was placed in a 1 dram shell vial with $0.2 \mathrm{~mL}$ of DCM. This solution was divided drop by drop onto two separate glass slides and allowed to dry. The slides were placed carefully in a glass vessel, which was sealed with septa, and cooled externally with a dry ice/acetonitrile bath $\left(-44{ }^{\circ} \mathrm{C}\right)$. This vessel was put under a vacuum, and $1.5 \mathrm{~mL}$ of $\mathrm{O}_{2}$ (excess) was syringed in under static vacuum. This was allowed to react in the solid state for an hour. A distinct color change was observed and corroborated by solid-state UV-vis spectroscopy (see below). It was then removed from the sealed vessel and immediately placed on a copper plate submerged in liquid nitrogen and a Raman spectrum collected with $532 \mathrm{~nm}$ laser on $10 \%$ power, $180 \mathrm{~s}$ acquisition times, 8-12 acquisitions, and $4 \mathrm{X}$ LWD objective.

To validate this method of preparing 3 , solid state UV-visible spectroscopy at $-40{ }^{\circ} \mathrm{C}$ was undertaken. Compound 1 ( $\left.0.002 \mathrm{~g}\right)$ was dissolved in DCM and allowed to evaporate on a cuvette placed on its side. This was sealed under nitrogen, transferred to the cooled UVvisible spectrometer, then reacted with excess $\mathrm{O}_{2}$. The reaction was monitored for $1 \mathrm{~h}$ until 3 had fully formed, as determined by the presence of features at 528 and $716 \mathrm{~nm}$ (Figure S15).

Preparation of LC-MS Samples of 3. Complex 1 (2.8 mg) was dissolved in $3 \mathrm{~mL}$ of toluene to form a $1.4 \mathrm{mM}$ solution. This was monitored by UV-vis, and $1 \mathrm{~mL}$ was removed via cold syringe and placed into a chilled mass spectroscopy vial. This was then taken over cold and checked by LC-MS immediately.

\section{ASSOCIATED CONTENT}

\section{Supporting Information}

The Supporting Information is available free of charge at https://pubs.acs.org/doi/10.1021/jacs.1c06911.

Experimental procedures, NMR, IR, GC-MS UV-vis, EPR, XAS, SXRD data, and DFT (PDF)

\section{Accession Codes}

CCDC 2094085 contains the supplementary crystallographic data for this paper. These data can be obtained free of charge via www.ccdc.cam.ac.uk/data request/cif, or by emailing data_request@ccdc.cam.ac.uk, or by contacting The Cambridge Crystallographic Data Centre, 12 Union Road, Cambridge CB2 1EZ, UK; fax: +44 1223336033.

\section{AUTHOR INFORMATION}

\section{Corresponding Author}

John S. Anderson - Department of Chemistry, The University of Chicago, Chicago, Illinois 60637, United States; 이이.org/0000-0002-0730-3018; Email: jsanderson@ uchicago.edu 


\section{Authors}

Kate A. Jesse - Department of Chemistry, The University of Chicago, Chicago, Illinois 60637, United States; () orcid.org/0000-0002-3527-4007

Sophie W. Anferov - Department of Chemistry, The University of Chicago, Chicago, Illinois 60637, United States

Kelsey A. Collins - Department of Chemistry, Northwestern University, Evanston, Illinois 60208, United States

Juan A. Valdez-Moreira - Department of Chemistry, Indiana University, Bloomington, Indiana 47405, United States

Maia E. Czaikowski - Department of Chemistry, The University of Chicago, Chicago, Illinois 60637, United States

Alexander S. Filatov - Department of Chemistry, The University of Chicago, Chicago, Illinois 60637, United States; orcid.org/0000-0002-8378-1994

Complete contact information is available at: https://pubs.acs.org/10.1021/jacs.1c06911

\section{Notes}

The authors declare no competing financial interest.

\section{ACKNOWLEDGMENTS}

This work was supported by the National Institutes of Health (R35 GM133470). We thank the University of Chicago for funding, the $3 \mathrm{M}$ Corporation for a NTFA to J.S.A., and the Sloan Foundation for a Research Fellowship to J.S.A. (FG2019-11497). We also thank the Research Computing Center at the University of Chicago for providing computing resources. We would like to than Dr. Josh Kurutz for assistance with NMR. We would like to thank Prof. Ethan Hill for helpful discussions regarding Fe-oxygen intermediates. We also thank professors Dave Harris, Danna Freedman, and Jeremy Smith for useful discussions and assistance with Mössbauer spectroscopy. We would like to thank A. Anferov for assistance building our Raman setup. We would like to thank S. J. and M. W. for helpful discussions. K. A. C. acknowledges support from the NSF GRFP through DGE-11842165. J. A. V-M. and J. S. acknowledges support from the NSF through grant CHE1900020. Some data reported here were collected at ChemMatCARS Sector 15 which is supported by the NSF under grant number NSF/CHE-1834750. This research used resources of the APS, a U.S. DOE Office of Science User Facility operated for the DOE Office of Science by Argonne National Laboratory under Contract No. DE-AC0206CH11357. We thank Dr. John Katsoudas and Dr. Joshua Wright for assistance with XAS collection at beamline 10-BM.

\section{REFERENCES}

(1) Bím, D.; Alexandrova, A. N. Local Electric Fields As a Natural Switch of Heme-Iron Protein Reactivity. ACS Catal. 2021, 11, 65346546.

(2) Kwon, H.; Basran, J.; Devos, J. M.; Suardíaz, R.; van der Kamp, M. W.; Mulholland, A. J.; Schrader, T. E.; Ostermann, A.; Blakeley, M. P.; Moody, P. C. E.; et al. Visualizing the protons in a metalloenzyme electron proton transfer pathway. Proc. Natl. Acad. Sci. U. S. A. 2020, 117, 6484-6490.

(3) Ward, M. B.; Scheitler, A.; Yu, M.; Senft, L.; Zillmann, A. S.; Gorden, J. D.; Schwartz, D. D.; Ivanović-Burmazović, I.; Goldsmith, C. R. Superoxide dismutase activity enabled by a redox-active ligand rather than metal. Nat. Chem. 2018, 10, 1207-1212.

(4) Morgenstern, A.; Jaszai, M.; Eberhart, M. E.; Alexandrova, A. N. Quantified electrostatic preorganization in enzymes using the geometry of the electron charge density. Chem. Sci. 2017, 8, 50105018.
(5) Fried, S. D.; Boxer, S. G. Electric fields and enzyme catalysis. Annu. Rev. Biochem. 2017, 86, 387-415.

(6) Sacramento, J. J. D.; Goldberg, D. P. Factors Affecting Hydrogen Atom Transfer Reactivity of Metal-Oxo Porphyrinoid Complexes. Acc. Chem. Res. 2018, 51, 2641-2652.

(7) Noodleman, L.; Han, W. G. Structure, redox, pKa, spin. A golden tetrad for understanding metalloenzyme energetics and reaction pathways. JBIC, J. Biol. Inorg. Chem. 2006, 11, 674-694.

(8) Siegbahn, P. E. M.; Blomberg, M. R. A. Quantum chemical studies of proton-coupled electron transfer in metalloenzymes. Chem. Rev. 2010, 110, 7040-7061.

(9) Warshel, A.; Dryga, A. Simulating electrostatic energies in proteins: Perspectives and some recent studies of $\mathrm{pK}$ as, redox, and other crucial functional properties. Proteins: Struct., Funct., Genet. 2011, 79, 3469-3484.

(10) Baumgardner, D. F.; Parks, W. E.; Gilbertson, J. D. Harnessing the active site triad: Merging hemilability, proton responsivity, and ligand-based redox-activity. Dalt. Trans. 2020, 49, 960-965.

(11) Gunasekera, P. S.; Abhyankar, P. C.; MacMillan, S. N.; Lacy, D. C. A Facially Coordinating Tris-Benzimidazole Ligand for Nonheme Iron Enzyme Models. Eur. J. Inorg. Chem. 2021, 2021 (7), 654-657.

(12) Ehudin, M. A.; Schaefer, A. W.; Adam, S. M.; Quist, D. A.; Diaz, D. E.; Tang, J. A.; Solomon, E. I.; Karlin, K. D. Influence of intramolecular secondary sphere hydrogen-bonding interactions on cytochrome: C oxidase inspired low-spin heme-peroxo-copper complexes. Chem. Sci. 2019, 10, 2893-2905.

(13) Onderko, E. L.; Silakov, A.; Yosca, T. H.; Green, M. T. Characterization of a selenocysteine-ligated $\mathrm{P} 450$ compound I reveals direct link between electron donation and reactivity. Nat. Chem. 2017, 9, 623-628.

(14) Yosca, T. H.; Ledray, A. P.; Ngo, J.; Green, M. T. A new look at the role of thiolate ligation in cytochrome P450. JBIC, J. Biol. Inorg. Chem. 2017, 22, 209-220.

(15) Ortiz De Montellano, P. R. Hydrocarbon hydroxylation by cytochrome P450 enzymes. Chem. Rev. 2010, 110 (2), 932-948.

(16) Denisov, I. G.; Makris, T. M.; Sligar, S. G.; Schlichting, I. Structure and chemistry of cytochrome P450. Chem. Rev. 2005, 105, 2253-2277.

(17) Meunier, B.; de Visser, S. P.; Shaik, S. Mechanism of oxidation reactions catalyzed by cytochrome P450 enzymes. Chem. Rev. 2004, 104, 3947-3980.

(18) Quist, D. A.; Diaz, D. E.; Liu, J. J.; Karlin, K. D. Activation of dioxygen by copper metalloproteins and insights from model complexes. JBIC, J. Biol. Inorg. Chem. 2017, 22, 253-288.

(19) Adam, S. M.; Wijeratne, G. B.; Rogler, P. J.; Diaz, D. E.; Quist, D. A.; Liu, J. J.; Karlin, K. D. Synthetic $\mathrm{Fe} / \mathrm{Cu}$ Complexes: Toward Understanding Heme-Copper Oxidase Structure and Function. Chem. Rev. 2018, 118 (22), 10840-11022.

(20) Hill, E. A.; Weitz, A. C.; Onderko, E.; Romero-Rivera, A.; Guo, Y.; Swart, M.; Bominaar, E. L.; Green, M. T.; Hendrich, M. P.; Lacy, D. C.; et al. Reactivity of an $\mathrm{Fe}^{\mathrm{IV}}$-Oxo Complex with Protons and Oxidants. J. Am. Chem. Soc. 2016, 138 (40), 13143-13146.

(21) Ford, C. L.; Park, Y. J.; Matson, E. M.; Gordon, Z.; Fout, A. R. A bioinspired iron catalyst for nitrate and perchlorate reduction. Science 2016, 354 (6313), 741-743.

(22) Gordon, Z.; Miller, T. J.; Leahy, C. A.; Matson, E. M.; Burgess, M.; Drummond, M. J.; Popescu, C. V.; Smith, C. M.; Lord, R. L.; Rodríguez-López, J.; et al. Characterization of Terminal Iron(III)-Oxo and Iron(III)-Hydroxo Complexes Derived from O2 Activation. Inorg. Chem. 2019, 58 (23), 15801-15811.

(23) Moore, C. M.; Szymczak, N. K. Redox-induced fluoride ligand dissociation stabilized by intramolecular hydrogen bonding. Chem. Commun. 2015, 51 (25), 5490-5492.

(24) Rauch, M.; Kar, S.; Kumar, A.; Avram, L.; Shimon, L. J. W.; Milstein, D. Metal-Ligand Cooperation Facilitates Bond Activation and Catalytic Hydrogenation with Zinc Pincer Complexes. J. Am. Chem. Soc. 2020, 142 (34), 14513-14521.

(25) Liao, Q.; Liu, T.; Johnson, S. I.; Klug, C. M.; Wiedner, E. S.; Morris Bullock, R.; Dubois, D. L. Evaluation of attractive interactions 
in the second coordination sphere of iron complexes containing pendant amines. Dalt. Trans. 2019, 48 (15), 4867-4878.

(26) Pegis, M. L.; Martin, D. J.; Wise, C. F.; Brezny, A. C.; Johnson, S. I.; Johnson, L. E.; Kumar, N.; Raugei, S.; Mayer, J. M. Mechanism of Catalytic $\mathrm{O}_{2}$ Reduction by Iron Tetraphenylporphyrin. J. Am. Chem. Soc. 2019, 141, 8315-8326.

(27) Macleod, K. C.; Lewis, R. A.; Derosha, D. E.; Mercado, B. Q.; Holland, P. L. C-H and C-N Activation at Redox-Active Pyridine Complexes of Iron. Angew. Chem., Int. Ed. 2017, 56, 1069-1072.

(28) Loewen, N. D.; Thompson, E. J.; Kagan, M.; Banales, C. L.; Myers, T. W.; Fettinger, J. C.; Berben, L. A. A pendant proton shuttle on $\left[\mathrm{Fe}_{4} \mathrm{~N}(\mathrm{CO})_{12}\right]^{-}$alters product selectivity in formate vs. $\mathrm{H}_{2}$ production via the hydride $\left[\mathrm{H}-\mathrm{Fe}_{4} \mathrm{~N}(\mathrm{CO})_{12}\right]^{-}$. Chem. Sci. 2016, 7, $2728-2735$

(29) Helm, M. L.; Stewart, M. P.; Bullock, M. R.; DuBois, M. R.; DuBois, D. L. A Synthetic Nickel Electrocatalyst with a Turnover Frequency Above 100,000 s-1 for $\mathrm{H}_{2}$ Production. Science 2011, 333, $863-867$.

(30) Dubois, M. R.; Dubois, D. L. Development of Molecular Electrocatalysts for $\mathrm{CO}_{2}$ Reduction and $\mathrm{H}_{2}$ Production/Oxidation. Acc. Chem. Res. 2009, 42 (12), 1974-1982.

(31) Harris, C. F.; Bayless, M. B.; Van Leest, N. P.; Bruch, Q. J.; Livesay, B. N.; Bacsa, J.; Hardcastle, K. I.; Shores, M. P.; De Bruin, B.; Soper, J. D. Redox-Active Bis(phenolate) N-Heterocyclic Carbene [OCO] Pincer Ligands Support Cobalt Electron Transfer Series Spanning Four Oxidation States. Inorg. Chem. 2017, 56, 1242112435 .

(32) Bagh, B.; Broere, D. L. J.; Sinha, V.; Kuijpers, P. F.; Van Leest, N. P.; De Bruin, B.; Demeshko, S.; Siegler, M. A.; Van Der Vlugt, J. I. Catalytic Synthesis of N-Heterocycles via Direct C $\left(\mathrm{sp}^{3}\right)-\mathrm{H}$ Amination Using an Air-Stable Iron(III) Species with a Redox-Active Ligand. J. Am. Chem. Soc. 2017, 139, 5117-5124.

(33) Sinha, S.; Das, S.; Sikari, R.; Parua, S.; Brandaõ, P.; Demeshko, S.; Meyer, F.; Paul, N. D. Redox Noninnocent Azo-Aromatic Pincers and Their Iron Complexes. Isolation, Characterization, and Catalytic Alcohol Oxidation. Inorg. Chem. 2017, 56, 14084-14100.

(34) Broere, D. L. J.; Van Leest, N. P.; De Bruin, B.; Siegler, M. A.; Van Der Vlugt, J. I. Reversible Redox Chemistry and Catalytic C $\left(\mathrm{sp}^{3}\right)$ $\mathrm{H}$ Amination Reactivity of a Paramagnetic Pd Complex Bearing a Redox-Active o-Aminophenol-Derived NNO Pincer Ligand. Inorg. Chem. 2016, 55, 8603-8611.

(35) Liu, T.; Liao, Q.; O’Hagan, M.; Hulley, E. B.; DuBois, D. L.; Bullock, R. M. Iron Complexes Bearing Diphosphine Ligands with Positioned Pendant Amines as Electrocatalysts for the Oxidation of $\mathrm{H}_{2}$. Organometallics 2015, 34 (12), 2747-2764.

(36) Luca, O. R.; Crabtree, R. H. Redox-Active Ligands in Catalysis. Chem. Soc. Rev. 2013, 42, 1440-1459.

(37) Wong, J. L.; Sanchez, R. H.; Logan, J. G.; Zarkesh, R. A.; Zillera, J. W.; Heyduk, A. F. Disulfide Reductive Elimination from an Iron(III) Complex. Chem. Sci. 2013, 4, 1906-1910.

(38) Lyaskovskyy, V.; De Bruin, B. Redox non-innocent ligands: Versatile new tools to control catalytic reactions. ACS Catal. 2012, 2, 270-279.

(39) Kaim, W. Manifestations of Noninnocent Ligand Behavior. Inorg. Chem. 2011, 50, 9752-9765.

(40) Chirik, P. J.; Wieghardt, K. Radical Ligands Confer Nobility on Base-Metal Catalysts. Science 2010, 327, 794-795.

(41) Wegeberg, C.; Browne, W. R.; McKenzie, C. J. Cis Donor Influence on O-O Bond Lability in Iron(III) Hydroperoxo Complexes: Oxidation Catalysis and Ligand Transformation. Inorg. Chem. 2019, 58 (14), 8983-8994.

(42) Kal, S.; Que, L. Activation of a Non-Heme Fe $\mathrm{Fe}^{\mathrm{III}}-\mathrm{OOH}$ by a Second $\mathrm{Fe}^{\mathrm{III}}$ to Hydroxylate Strong C-H Bonds : Possible Implications for Soluble Methane Monooxygenase. Angew. Chem., Int. Ed. 2019, $158,8484-8488$.

(43) Xu, S.; Veach, J. J.; Oloo, W. N.; Peters, K. C.; Wang, J.; Perry, R. H.; Que, L. Detection of a transient $\mathrm{Fe}^{\mathrm{V}}(\mathrm{O})(\mathrm{OH})$ species involved in olefin oxidation by a bio-inspired non-haem iron catalyst. Chem. Commun. 2018, 54 (63), 8701-8704.
(44) Serrano-Plana, J.; Acuña-Parés, F.; Dantignana, V.; Oloo, W. N.; Castillo, E.; Draksharapu, A.; Whiteoak, C. J.; Martin-Diaconescu, V.; Basallote, M. G.; Luis, J. M.; et al. Acid-Triggered O-O Bond Heterolysis of a Nonheme $\mathrm{Fe}^{\mathrm{III}}(\mathrm{OOH})$ Species for the Stereospecific Hydroxylation of Strong C-H Bonds. Chem. - Eur. J. 2018, 24 (20), $5331-5340$.

(45) Widger, L. R.; Jiang, Y.; McQuilken, A. C.; Yang, T.; Siegler, M. A.; Matsumura, H.; Moënne-Loccoz, P.; Kumar, D.; de Visser, S. P.; David, P. G. Thioether-ligated iron(II) and iron(III)-hydroperoxo/ alkylperoxo complexes with an H-bond donor in the second coordination sphere $\dagger$. Dalt. Trans. 2014, 43, 7522-7532.

(46) Li, F.; Meier, K. K.; Cranswick, M. A.; Chakrabarti, M.; Heuvelen, K. M. V.; Eckard, M.; Que, L. Characterization of a HighSpin Non-Heme $\mathrm{Fe}(\mathrm{III})-\mathrm{OOH}$ Intermediate and Its Quantitative Conversion to an $\mathrm{Fe}(\mathrm{IV})=\mathrm{O}$ Complex. J. Am. Chem. Soc. 2011, 133, 7256.

(47) Cho, J.; Jeon, S.; Wilson, S. A.; Liu, L. V.; Kang, E. A.; Braymer, J. J.; Lim, M. H.; Hedman, B.; Hodgson, K. O.; Valentine, J. S.; et al. Structure and reactivity of a mononuclear non-haem iron(III)-peroxo complex. Nature 2011, 180 (5), 8-11.

(48) Nam, E.; Alokolaro, P. E.; Swartz, R. D.; Gleaves, M. C.; Pikul, J.; Kovacs, J. A. Investigation of the Mechanism of Formation of a Thiolate-Ligated Fe (III) -OOH. Inorg. Chem. 2011, 13, 1592-1602.

(49) Shearer, J.; Scarrow, R. C.; Kovacs, J. A. Synthetic Models for the Cysteinate-Ligated Non-Heme Iron Enzyme Superoxide Reductase : Observation and Structural Characterization by XAS of an Fe III - OOH Intermediate. J. Am. Chem. Soc. 2002, 124, 11709-11717.

(50) Simaan, A. J.; Girerd, J.; Wieghardt, K.; Bill, E. The Electronic Structure of Non-Heme Iron(III) - Hydroperoxo and Iron(III) Peroxo Model Complexes Studied by Mössbauer and Electron Paramagnetic Resonance Spectroscopies. Inorg. Chem. 2001, 40, $6538-6540$.

(51) Kovacs, J. A.; Brines, L. M. Understanding how the thiolate sulfur contributes to the function of the non-heme iron enzyme superoxide reductase. Acc. Chem. Res. 2007, 40, 501-509.

(52) Blakely, M. N.; Dedushko, M. A.; Chaau, P.; Poon, Y.; Villaracevedo, G.; Kovacs, J. A. Formation of a Reactive, Alkyl ThiolateLigated $\mathrm{Fe}$ (III)-Superoxo Intermediate Derived from Dioxygen. J. Am. Chem. Soc. 2019, 3, 8-11.

(53) Jiang, Y.; Telser, J.; Goldberg, D. P. Evidence for the formation of a mononuclear ferric-hydroperoxo complex via the reaction of dioxygen with an $\left(\mathrm{N}_{4} \mathrm{~S}\right.$ (thiolate) $)$ iron(II) complex. Chem. Commun. 2009, 6828-6830.

(54) Charette, B. J.; Ziller, J. W.; Heyduk, A. F. Metal-Ion Influence on Ligand-Centered Hydrogen-Atom Transfer. Inorg. Chem. 2021, 60, $1579-1589$.

(55) Sherbow, T. J.; Thompson, E. J.; Arnold, A.; Sayler, R. I.; Britt, R. D.; Berben, L. A. Electrochemical Reduction of $\mathrm{N}_{2}$ to $\mathrm{NH}_{3}$ at Low Potential by a Molecular Aluminum Complex. Chem. - Eur. J. 2019, $25,454-458$.

(56) Drummond, M. J.; Ford, C. L.; Gray, D. L.; Popescu, C. V.; Fout, A. R. Radical Rebound Hydroxylation Versus H-Atom Transfer in Non-Heme Iron(III)-Hydroxo Complexes: Reactivity and Structural Differentiation. J. Am. Chem. Soc. 2019, 141, 6639-6650.

(57) Rosenkoetter, K. E.; Wojnar, M. K.; Charette, B. J.; Ziller, J. W.; Heyduk, A. F. Hydrogen-Atom Noninnocence of a Tridentate [SNS] Pincer Ligand. Inorg. Chem. 2018, 57, 9728-9737.

(58) Pramanick, R.; Bhattacharjee, R.; Sengupta, D.; Datta, A.; Goswami, S. An Azoaromatic Ligand as Four Electron Four Proton Reservoir: Catalytic Dehydrogenation of Alcohols by Its Zinc(II) Complex. Inorg. Chem. 2018, 57 (12), 6816-6824.

(59) Jain, R.; Mamun, A. Al; Buchanan, R. M.; Kozlowski, P. M.; Grapperhaus, C. A. Ligand-Assisted Metal-Centered Electrocatalytic Hydrogen Evolution upon Reduction of a Bis(thiosemicarbazonato)$\mathrm{Ni}(\mathrm{II})$ Complex. Inorg. Chem. 2018, 57, 13486-13493.

(60) Schneck, F.; Finger, M.; Tromp, M.; Schneider, S. Chemical Non-Innocence of an Aliphatic PNP Pincer Ligand. Chem. - Eur. J. 2017, 23 (1), 33-37. 
(61) Margulieux, G. W.; Bezdek, M. J.; Turner, Z. R.; Chirik, P. J. Ammonia Activation, $\mathrm{H}_{2}$ Evolution and Nitride Formation from a Molybdenum Complex with a Chemically and Redox Noninnocent Ligand. J. Am. Chem. Soc. 2017, 139, 6110-6113.

(62) Dauth, A.; Gellrich, U.; Diskin-Posner, Y.; Ben-David, Y.; Milstein, D. The Ferraquinone-Ferrahydroquinone Couple: Combining Quinonic and Metal-Based Reactivity. J. Am. Chem. Soc. 2017, 139 (7), 2799-2807.

(63) Lindley, B. M.; Bruch, Q. J.; White, P. S.; Hasanayn, F.; Miller, A. J. M. Ammonia Synthesis from a Pincer Ruthenium Nitride via Metal-Ligand Cooperative Proton-Coupled Electron Transfer. J. Am. Chem. Soc. 2017, 139 (15), 5305-5308.

(64) Delgado, M.; Gilbertson, J. D. Ligand-based reduction of nitrate to nitric oxide utilizing a proton-responsive secondary coordination sphere. Chem. Commun. 2017, 53 (81), 11249-11252.

(65) Lagaditis, P. O.; Schluschaß, B.; Demeshko, S.; Würtele, C.; Schneider, S. Square-Planar Cobalt(III) Pincer Complex. Inorg. Chem. 2016, 55 (9), 4529-4536.

(66) Henthorn, J. T.; Agapie, T. Modulation of Proton-Coupled Electron Transfer through Molybdenum-Quinonoid Interactions. Inorg. Chem. 2016, 55, 5337-5342.

(67) Myers, T. W.; Berben, L. A. Aluminium-ligand cooperation promotes selective dehydrogenation of formic acid to $\mathrm{H}_{2}$ and $\mathrm{CO}_{2}$. Chem. Sci. 2014, 5, 2771.

(68) Purse, B. W.; Tran, L. H.; Piera, J.; Åkermark, B.; Bäckvall, J. E. Synthesis of new hybrid hydroquinone/cobalt schiff base catalysts: Efficient electron-transfer mediators in aerobic oxidation. Chem. - Eur. J. 2008, 14 (25), 7500-7503.

(69) McNeece, A. J.; Jesse, K. A.; Filatov, A. S.; Schneider, J. E.; Anderson, J. S. Catalytic hydrogenation enabled by ligand-based storage of hydrogen. Chem. Commun. 2021, 57 (32), 3869-3872.

(70) Mcneece, A. J.; Jesse, K. A.; Xie, J.; Filatov, A. S.; Anderson, J. S. Generation and Oxidative Reactivity of a Ni(II) Superoxo Complex via Ligand-Based Redox Non-Innocence. J. Am. Chem. Soc. 2020, 142, 10824-10832.

(71) Addison, A. W.; Rao, N. T. Synthesis, Structure, and Spectroscopic Properties of Copper(II) Compounds containing Nitrogen-Sulfur Donor Ligands ; the Crystal and Molecular structure of Aqua[1,7-bis(N-methylbenzimidazol-2'-yl)-2,6-dithiaheptane]copper(II)Perchlorate. J. Chem. Soc., Dalton Trans. 1984, 1349-1356. (72) Zheng, H.; Langner, K. M.; Shields, G. P.; Hou, J.; Kowiel, M.; Allen, F. H.; Murshudov, G.; Minor, W. Data mining of iron(II) and iron(III) bond-valence parameters, and their relevance for macromolecular crystallography. Acta Crystallogr. Sect. D Struct. Biol. 2017, 73, 316-325.

(73) Nishida, Y.; Kida, S. Crystal Structures of Low- and High-spin $\mathrm{Fe}$ (III) Complexes with Quadridentate Schiff Bases. J. Chem. Soc., Dalton Trans. 1987, 1157-1161.

(74) Evans, D. F. The Determination of the Paramagnetic Susceptibility. J. Chem. Soc. 1959, 2003-2005.

(75) Bain, G. A.; Berry, J. F. Diamagnetic corrections and Pascal's constants. J. Chem. Educ. 2008, 85 (4), 532-536.

(76) Noh, H.; Cho, J. Synthesis, characterization and reactivity of non-heme 1st row transition metal-superoxo intermediates. Coord. Chem. Rev. 2019, 382, 126-144.

(77) Kim, Y. M.; Cho, K.-B.; Cho, J.; Wang, B.; Chunsen, L.; Shaik, S.; Nam, W. A Mononuclear Non-Heme High-Spin Iron(III) Hydroperoxo Complex as an Active Oxidant in Sulfoxidation Reactions. J. Am. Chem. Soc. 2013, 135, 8838-8841.

(78) Schäfer, A.; Horn, H.; Ahlrichs, R. Fully optimized contracted Gaussian basis sets for atoms Li to Kr. J. Chem. Phys. 1992, 97 (4), 2571-2577.

(79) Schäfer, A.; Horn, H.; Ahlrichs, R. Fully optimized contracted Gaussian basis sets of triple zeta valence quality for atoms $\mathrm{Li}$ to $\mathrm{Kr}$. J. Chem. Phys. 1994, 100 (8), 5829-5835.

(80) Weigend, F.; Ahlrichs, R. Balanced basis sets of split valence, triple zeta valence and quadruple zeta valence quality for $\mathrm{H}$ to $\mathrm{Rn}$ : Design and assessment of accuracy. Phys. Chem. Chem. Phys. 2005, 7 (18), 3297-3305.
(81) Römelt, M.; Ye, S.; Neese, F. Calibration of modern density functional theory methods for the prediction of ${ }^{57} \mathrm{Fe}$ Mössbauer isomer shifts: Meta-GGA and double-hybrid functionals. Inorg. Chem. 2009, 48 (3), 784-785.

(82) Dolg, M.; Wedig, U.; Stoll, H.; Preuss, H. Energy-adjusted ab initio pseudopotentials for the first row transition elements. J. Chem. Phys. 1987, 86 (2), 866-872.

(83) Battistella, B.; Ray, K. $\mathrm{O} 2$ and $\mathrm{H} 2 \mathrm{O} 2$ activations at dinuclear $\mathrm{Mn}$ and $\mathrm{Fe}$ active sites. Coord. Chem. Rev. 2020, 408, 213176.

(84) Baglia, R. A.; Zaragoza, J. P. T.; Goldberg, D. P. Biomimetic Reactivity of Oxygen-Derived Manganese and Iron Porphyrinoid Complexes. Chem. Rev. 2017, 117 (21), 13320-13352.

(85) Jesse, K. A.; Chang, M.; Filatov, A. S.; Anderson, J. S. Iron(II) Complexes Featuring a Redox-Active Dihydrazonopyrrole Ligand. $Z$. Anorg. Allg. Chem. 2021, 647, 1-7.

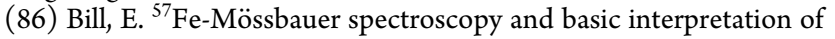
Mössbauer parameters. In Practical Approaches to Biological Inorganic Chemistry; 2020; pp 201-228.

(87) Żamojé, K.; Zdrowowicz, M.; Rudnicki-Velasquez, P. B.; Krzymiński, K.; Zaborowski, B.; Niedziałkowski, P.; Jacewicz, D.; Chmurzyński, L. The development of 1,3-diphenylisobenzofuran as a highly selective probe for the detection and quantitative determination of hydrogen peroxide. Free Radical Res. 2017, 51, 38-46.

(88) Mann, S. I.; Heinisch, T.; Ward, T. R.; Borovik, A. S. Peroxide Activation Regulated by Hydrogen Bonds within Artificial $\mathrm{Cu}$ Proteins. J. Am. Chem. Soc. 2017, 139 (48), 17289-17292. 